\title{
Amyloid-Beta: A Crucial Factor in Alzheimer's Disease
}

\author{
Saeed Sadigh-Eteghad Babak Sabermarouf Alireza Majdi Mahnaz Talebi \\ Mehdi Farhoudi Javad Mahmoudi
}

Neurosciences Research Center, Tabriz University of Medical Sciences, Tabriz, Iran

\section{Key Words}

Alzheimer's disease · Amyloid-beta · Pathobiology

\begin{abstract}
Alzheimer's disease (AD) is the most prevalent form of dementia which affects people older than 60 years of age. In $A D$, the dysregulation of the amyloid-beta $(A \beta)$ level leads to the appearance of senile plaques which contain $A \beta$ depositions. $A \beta$ is a complex biological molecule which interacts with many types of receptors and/or forms insoluble assemblies and, eventually, its nonphysiological depositions alternate with the normal neuronal conditions. In this situation, AD signs appear and the patients experience marked cognitional disabilities. In general, intellect, social skills, personality, and memory are influenced by this disease and, in the long run, it leads to a reduction in quality of life and life expectancy. Due to the pivotal role of $A \beta$ in the pathobiology of $A D$, a great deal of effort has been made to reveal its exact role in neuronal dysfunctions and to finding efficacious therapeutic strategies against its adverse neuronal outcomes. Hence, the determination of its different molecular assemblies and the mechanisms underlying its pathological effects are of interest. In the present paper, some of the well-established structural forms of $A \beta$, its interactions with various receptors and possible molecular and cellular mechanisms underlying its neurotoxicity are discussed. In addition, several $A \beta$-based rodent models of $A D$ are reviewed.
\end{abstract}

(c) 2014 S. Karger AG, Basel

\begin{tabular}{ll}
\hline KARGER 125/s & $\begin{array}{l}\text { ( } 2014 \text { S. Karger AG, Basel } \\
\text { 1011-7571/14/0241-0001\$39.50/0 }\end{array}$ \\
$\begin{array}{l}\text { E-Mail karger@karger.com } \\
\text { www.karger.com/mpp }\end{array}$ & $\begin{array}{l}\text { This is an Open Access article licensed under the terms of the } \\
\text { Creative Commons Attribution-NonCommercial 3.0 Un- } \\
\text { ported license (CC BY-NC) (www.karger.com/OA-license), } \\
\text { applicable to the online version of the article only. Distribu- } \\
\text { tion permitted for non-commercial purposes only. }\end{array}$
\end{tabular}

\section{Introduction}

Alzheimer's disease (AD) was first described by the German psychiatrist, Alois Alzheimer, in the early 1900s [1] and is now considered the most prevalent progressive neurodegenerative disorder, responsible for $75 \%$ of all dementia cases $[2,3]$. It affects approximately 35.6 million people worldwide. This will increase with population aging [4] and will probably affect nearly 106.8 million people by 2050 [5]. It causes mental and cognitive deficits such as impaired memory, intellect and personality disorder in people older than 65 years of age $[6,7]$. In the advanced stages of the disease central sensory procedures, including the visual system, get affected, too [8]. Collectively, ADassociated problems decrease life expectancy, reduce quality of life, cause physical disability [3], and eventually lead to serious problems in daily life activities such as social and occupational functions [9]. To reduce the social and economic costs and the burden of the disease on patients and their families, some remarkable efforts have lately been made to find diagnostic markers which predict the disease earlier [5]. Neuroimaging methods such as magnetic resonance imaging and positron emission tomography have been developed to enable researchers to diagnose AD in its early stages $[10,11]$. Also, several biomarkers, which are crucial in detecting pathological features of $\mathrm{AD}$, have been found in cerebrospinal fluid (CSF) and can be assessed [12]. From a histological viewpoint, the progression of $\mathrm{AD}$ is associated with 3 cardinal neuropathological features:

Javad Mahmoudi

Neurosciences Research Center

Tabriz University of Medical Sciences

Tabriz (Iran)

E-Mail mahmoudi2044@yahoo.com 


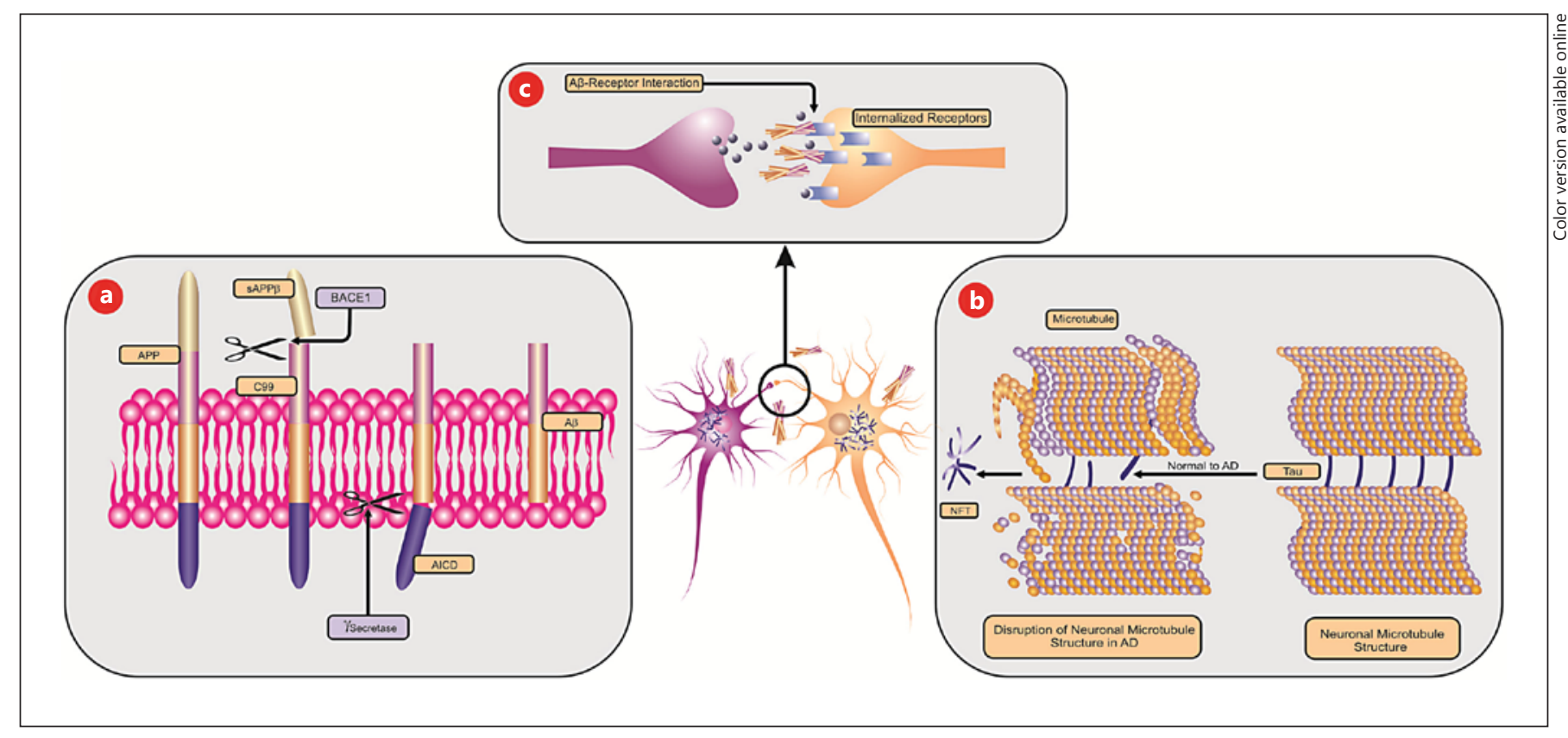

Fig. 1. The 3 major features of $\mathrm{AD}$ within the neuronal system. a Cleavage of APP, and formation and accumulation of extraneuronal $A \beta$. b Formation and deposition of intraneuronal NFTs. c Synaptic dysfunction due to A $\beta$ accumulation and its interaction with receptors. AICD = APP intracellular domain.

the accumulation of extracellular senile plaques which is mediated by amyloid-beta $(A \beta)$, intracellular neurofibrillary tangles (NFT) and synaptic degeneration (fig. 1) [13, 14]. These events mainly occur in the neocortex, hippocampus, and other subcortical regions which are necessary for cognitive function [15]. The appearance of these markers apparently occurs many years prior to the clinical signs and symptoms of the disease, hence they could be good markers for $\mathrm{AD}$ prediction [5]. Meanwhile, $\mathrm{A} \beta$ peptide is an important risk factor and has a central role in the onset and progression of $\mathrm{AD}[16] . \mathrm{A} \beta$ is produced in normal individuals but, under certain circumstances, this molecule may aggregate and start disease progression. There is a large body of evidence emphasizing that $A \beta$ oligomers play the main role in neuronal dysfunction and $\operatorname{AD}[17,18]$. In this article, the points that link $\mathrm{AD}$ to various aspects of $\mathrm{A} \beta$ pathoneurobiology are reviewed, which may help us understand the process of the disease more clearly.

\section{Generation and Clearance of $A \beta$}

Amyloid precursor protein (APP) is a single-pass transmembrane protein which is expressed at high levels in the brain and metabolized in a rapid and highly com- plex fashion [19]. The APP is cleaved by two pathways. In the nonamyloidogenic pathway, the full-length APP is cleaved by $\alpha$ - and $\gamma$-secretases. Cleavage via the $\beta$ - and $\gamma$-secretases can be promiscuous and produces several species of $A \beta$ fragments.

$\beta$-Site APP-cleaving enzyme 1 (BACE1) is the major $\beta$-secretase in the brain [20]. Neurotoxic forms of $A \beta$ created by cleavage of APP initially by BACE1 produce the C99 fragment and soluble $\mathrm{APP} \beta$, and the $\mathrm{C} 99$ is then cleaved by $\gamma$-secretase to produce $A \beta$ (fig. 1a) [21-23]. Moreover, both presenilin 1 (PSEN1) and 2 (PSEN2) regulate the proteolytic function of $\gamma$-secretase, and mutations in these proteins can change the activity of $\gamma$-secretase and increase the ratio of $A \beta$ in early-onset forms of $A D$ [24].

It has also been suggested that increased levels of free cholesterol in neuronal cell membranes may provoke $A \beta$ formation [25]. Both clinical and genetic data emphasize the unique role of $\mathrm{A} \beta$ in the pathogenesis of $\mathrm{AD}$ [26].

Based on etiological, pathological, genetic, and biochemical aspects of the disease, $\mathrm{AD}$ is divided into two major forms: familial and sporadic $[6,27]$. It has been known that mutations within the APP gene result in the appearance of familial-type (early-onset autosomal-dominant) $\mathrm{AD}$. On the other hand, the existence of an extra 
copy of the APP gene, as in patients with Down's syndrome, predominantly leads to the development of $\mathrm{AD}$ in the fifth decade of life [28]. In young brains and under normal conditions, there is an equilibrium between the production and elimination of $A \beta$ that maintains $A \beta$ at constant levels, which is known as steady state [29]. However, in aging and pathological conditions such as metabolic disorders and excitotoxicity, the formation and clearance of $A \beta$ have disturbances [21] that lead to an accumulation of $A \beta$ and senile plaque formation [3].

The imbalance of the $\mathrm{A} \beta$ level in $\mathrm{AD}$ may be due to its production and clearance in the brain. There are different pathways such as the activation of degrading enzymes, receptor-mediated cellular and vascular clearance and other mechanisms by which $A \beta$ is cleared in the brain [30-33]. Some receptors such as low-density lipoprotein receptorrelated protein 1 (LRP1) play an important role in the receptor-mediated clearance of $A \beta[30]$. Studies have shown that conditional knockout of LRP1 in mouse forebrain neurons increased brain $A \beta$ levels and exacerbated amyloid plaque deposition selectively in the cortex [30]. Also, $\mathrm{P}$-glycoprotein has been suggested to be involved in $A \beta$ clearance as an $A \beta$ efflux pump at the blood-brain barrier (BBB) [31]. Experimental studies have shown that the ablation of $\mathrm{P}$-glycoprotein at the $\mathrm{BBB}$ enhanced $\mathrm{A} \beta$ deposition in the brain of an $\mathrm{AD}$ mouse model [32].

Furthermore, $A \beta$ is degraded by several peptidases, principally two zinc metalloendopeptidases referred to as neprilysin and insulin-degrading enzyme [33]. Studies have shown that neprilysin knockout mice have increased levels of $A \beta$ peptides in the brain. Moreover, the activity of neprilysin is reduced in the cortex and hippocampus of $\mathrm{AD}$ patients [34]. Insulin-degrading enzyme is another regulator of $A \beta$ levels in neuronal cells. Genetic studies have shown that insulin-degrading enzyme gene variations are associated with the clinical symptoms of $\mathrm{AD}$ [35]. Endothelin-converting enzyme is another degrading enzyme which is expressed in neural tissues, cleaves 'big endothelin' to produce the vasoconstrictor endothelin-1 and has a principal role in the degradation of $A \beta$ [36].

Population studies have demonstrated that apolipoprotein $\mathrm{E}$ (ApoE) $\varepsilon 4$ allele is a strong risk factor for lateonset AD [27]. ApoE, the dominant cholesterol and lipid carrier in the brain, is critical for $\mathrm{A} \beta$ catabolism. Also, ApoE receptors have been implicated in the clearance of $A \beta$ across the $\mathrm{BBB}$ in $\mathrm{AD}$ [37]. Impaired clearance of $A \beta$ may also cause sporadic $A D$ through interactions with ApoE4, decreased catabolism of $A \beta$ via reduced proteolytic enzymes, impaired transport across the $\mathrm{BBB}$, or impaired CSF transport [38].

$A \beta$ : A Crucial Factor in $A D$

\section{Concentration-Related Behavior of $A \beta$}

Interestingly, it should be pointed out that a very low amount of $A \beta$ may have a role in neural development [39] and in the regulation of cholinergic neurotransmission [21]. It has been demonstrated that $A \beta_{1-40}$ at a nanomolar concentration inhibits the oxidation of CSF and plasma lipoproteins [40]. Besides, neurons in response to oxidative conditions overexpress $A \beta$ to attenuate oxidative stress outcomes. The in vitro evaluations of the antioxidant activity of $A \beta$ have demonstrated that it is able to protect neurons from neurotoxicity in a concentrationdependent manner [28]. A $\beta$ that accumulates along cerebral blood vessels is known as cerebral amyloid angiopathy. This is frequently seen in $\mathrm{AD}$ cases and represents one of AD's histopathological hallmarks. [41]. It causes vasoconstriction and dysregulation of vascular tone.

Hence, it appears that $A \beta$ in higher concentrations, besides neurotoxicity, impairs blood flow within the cerebral structure and accelerates neuronal dysfunction.

\section{Structure-Related Toxicity}

$\mathrm{A} \beta$ assemblies are divided into three distinct groups (based on length, molecular weight, and microscopic dimensions) as follows: (1) very short oligomers, (2) A $\beta$ derived diffusible ligands and (3) protofibrils. Very short oligomers of $A \beta$ are referred to as dimmer and hexamer forms of $A \beta$. A $\beta$-derived diffusible ligands are small oligomers and their molecular weights range from 17 to $42 \mathrm{kDa}$ [26]. Finally, protofibrils are transient structures which appear prior to the formation of mature amyloid fibrils and can be named prefibrillar assemblies [29].

In their aggregated form, these peptides are able to induce neurotoxicity [15]. This ability, along with the appearance of novel structures, disrupts synaptic functions [29]. A $\beta$ in its specific structural forms provokes nitric oxide formation and an influx of calcium ions which might eventually lead to the formation of peroxynitrite radicals and cell death [42].

It is to be noted that the accumulation of soluble oligomers (nonfibrillar), but not of monomers or insoluble assemblies, has the same neurotoxic effects $[43,44]$. Interestingly, some studies have indicated that soluble forms of $A \beta$ can impair long-term potentiation and avoidance learning in animal models [45]. Moreover, some of the biological events such as the production of new proteins and the generation of dendritic spines which are involved in memory functions are influenced by the soluble form of $A \beta$ [46]. 
Therefore, neurodegeneration in $\mathrm{AD}$ is mediated in part through soluble forms of $A \beta$. This form of $A \beta$ is increased in the brain of AD patients [44] and is detectable in their CSF and plasma [47]. Some studies have demonstrated that soluble $\mathrm{A} \beta$ concentration correlates with cognitive decline in AD-affected individuals [43]. Hence, it may be considered as a reliable predictor of AD [28]. This idea is also supported by animal studies [48, 49], in which soluble forms of $\mathrm{A} \beta$ levels correlate with $\mathrm{AD}$ progress in the transgenic mouse model of $\mathrm{AD}$ but plaque numbers or insoluble $A \beta$ levels have no significant relationship with the severity of $\mathrm{AD}$ [48]. Based on these findings, some recent studies have shown that $A \beta$ dimers isolated from human brains are the most toxic species of peptide $[49,50]$.

Overall, aggregated forms, soluble oligomers and insoluble assemblies of $A \beta$ impair synaptic activity and induce neuritis as well as triggering neurodegeneration [50] and alternating synaptic proteins in $\mathrm{AD}$ [43].

\section{$A \beta$ Interactions with Receptors}

Ryanodine receptors are expressed in the soma, proximal dendrites, and distal processes and spines of neuronal cells [51]. It has been shown that $A \beta$ increases the expression and activity of ryanodine receptor 3 and subsequently these receptors disrupt intracellular $\mathrm{Ca}^{2+}$ levels. The disruption of intracellular $\mathrm{Ca}^{2+}$ homeostasis may have a role in AD pathology [52].

Also, N-methyl-D-aspartate (NMDA) receptor stimulation and intracellular signaling of AMPA ( $\alpha$-amino-3hydroxy-5-methyl-4-isoxazolepropionic acid) receptor trafficking are influenced by the soluble form of $A \beta$ [46]. $\mathrm{A} \beta$ interacts with NMDA receptors, which are responsible for maintaining glutamate homeostasis within the neurons. Dysregulation of this hemostasis may lead to excitotoxicity and impacts on the neuronal plasticity [53].

LRP1 is a transmembrane protein which acts as a signaling receptor and cargo transporter. It has some essential neural functions, including the process of APP and modulation of the toxicity of the resulting $A \beta$. Furthermore, LPR1 modulates NMDA receptor function [54]. LRP1 and its ligands, ApoE and $\alpha_{2}$-macroglobulin, are involved in $\mathrm{A} \beta$ deposition through sequestration and removal of its soluble forms [55].

Sorting protein-related receptor (sorLA) is another low-density lipoprotein receptor family which is expressed in neurons and controls APP trafficking/processing and regulates its conversion to $\mathrm{A} \beta[56]$. AD progression disrupts the expression of sorLA and its regulatory function [57]. sorLA gene-inherited variants may regulate the tissue-specific expression of sorLA, which may be associated with late-onset $\mathrm{AD}$ [58].

CD36 is an innate immunity receptor which is present in endothelial cells and microglia. It binds to $A \beta$ and activates reactive oxygen species production, vasoconstriction, and vascular tone dysregulation. Collectively, these events may provoke neuronal damage in disease progress [59].

$\mathrm{N}$-formyl peptide receptor like-1 (FPRL-1) is a seventransmembrane, G-protein-coupled receptor. It is expressed on human mononuclear monocytes like microglia. $A \beta_{1-42}$ is a chemotactic agonist for this receptor. Following infiltrating senile plaques in the brain of $\mathrm{AD}$ patients, its expression is increased in inflammatory cells. Thus, this receptor may have a role in inflammation seen in $\mathrm{AD}[60]$.

Moreover, $A \beta$ interacts with other receptors such as tyrosine kinase (TrkA), pan-neurotrophin p75 (p75NTR) and $\alpha 7$ nicotinic acetylcholine (nAChR) [61].

Several neurotrophin signaling pathways may be activated in response to $A \beta$. $A \beta$ increases the nerve growth factor and its receptor TrkA expression [62]. In addition, the interaction of $A \beta$ with p75NTR has a pivotal role in $\mathrm{AD}$ pathogenesis. Cholinergic basal forebrain neurons express p75NTR receptors and $A \beta$ may induce apoptosis through these receptors [61]. Moreover, TrkA reduces $\beta$-cleavage of APP, whereas p75NTR activates this process. Also, normal aging activates $A \beta$ generation in the brain by 'switching' from the TrkA to the p75NTR receptor system [62].

The interaction of $\mathrm{A} \beta$ with $\alpha 7 \mathrm{nAChR}$ promotes the endocytosis of NMDA receptors and impairs normal cholinergic neurotransmission [29]. Furthermore, $A \beta$ shows antagonistic effects on $\alpha 7 \mathrm{nAChR}$ in a dose-dependent manner, and its pathological function may partially correlate with the blocking of these receptors [39].

\section{$A \beta$ and the Immune System}

In response to $\mathrm{A} \beta$-induced neurotoxicity in $\mathrm{AD}$, both humoral and cellular immunity are activated. Aging is commonly accompanied by a progressive dysregulation of the immune response, mainly due to alterations of cellular immunity. In comparison to these changes in cellular immunity, many features of innate immunity are relatively well maintained with age [63].

A number of publications have reported the presence of anti-A $\beta$ antibodies in the blood and CSF of patients 
with $\mathrm{AD}$ and healthy subjects [64]. Also, some drugs have recently been designed based on fully human anti$\mathrm{A} \beta$ monoclonal antibodies for the clearance of $\mathrm{A} \beta[65$, 66].

$A \beta$ deposition is responsible for microglia activation. $A \beta$ contributes to the enhancement of the inflammatory response by NF- $\kappa \mathrm{B}$ stimulation, a nuclear factor that is implicated in cytokine production and also regulates the ERK (extracellular signal-regulated kinase) and MAPK (mitogen-activated protein kinase) pathways that lead to cytokine and chemokine production [67]. Toll-like receptors (TLR) are important for regulating microglial responses to $A \beta$ and fibrillar $A \beta$ triggers microglia inflammatory cytokine production via TLR4-TLR6 heterodimers, whose assembly is regulated by CD36. Modification of the inflammatory state of microglia/macrophages may have an axial role in AD-related pathology [68].

\section{Prion-Like Mechanism of $A \beta$ Toxicity}

The concept of 'prion-like' has been suggested to explain the pathogenic mechanism of all the principal neurodegenerative disorders associated with protein misfolding, including AD [69].

Like prions, $A \beta$ peptides may fold in different manners, thus giving rise to 'strains' with specific pathological aspects. Also, $A \beta$ oligomers show a high affinity for binding to cellular prion protein $\left(\operatorname{Pr}^{\mathrm{C}}\right)$. $A \beta$ oligomers alter the activity of the Src family tyrosine kinase Fyn which participates in the $\mathrm{PrP}^{\mathrm{C}}$-regulated signaling pathway [70]. Also, $\mathrm{A} \beta$ binds to postsynaptic $\operatorname{PrP}^{\mathrm{C}}$ and activates Fyn to impair neural function [71]. It has been reported that NMDA receptors are necessary for the transduction of $A \beta$ toxic signaling [70]. Another study has indicated that the $\mathrm{A} \beta-\mathrm{PrP}^{\mathrm{C}}$ complex exerts its cytotoxicity via transmembrane LRP1 [72]. Additionally, the pattern of transmission and the spreading of $A \beta$ are similar to prions in the brain of $\mathrm{AD}$ patients [73].

\section{$A \beta$ and Neurofibrillary Tangles}

Tau is a microtubule-associated neuronal protein. It is generated by neurons and is localized in the cell body and axons [74, 75]. Under normal conditions, nerve growth factor increases tau expression during neuronal development [76]. However, in some pathological conditions it is also produced by glial cells [75, 77]. Although tau's main expression region is in the central nervous system, its mRNA is found in peripheral tissues, too [75]. In the brain, six tau isoforms are generated from a single gene through the alternative splicing of mRNA [74, 77]. Under normal conditions, tau promotes the assembly of tubulin into microtubules and maintains their stability $[78,79]$. Besides this function, it interacts with spectrin and actin filaments [75] and has a role in TrkA receptor-mediated signal transduction [74]. It is thought that tau abnormalities result in NFT production and neuronal death that eventually leads to dementia [80]. Accumulations of tau occur in a wide spectrum of neurodegenerative disorders such as progressive supranuclear palsy, corticobasal degeneration, Pick's disease, argyrophilic grain disease, the Parkinson-dementia complex of Guam, and AD [77]. The hyperphosphorylated form of tau protein exerts neurotoxic effects in these diseases which are collectively termed as tauopathies [74]. Tau in its hyperphosphorylated forms accumulates in somatodendritic parts of the neurons and becomes the core component of NFTs [76]. NFTs are structurally paired helical filaments which are composed of hyperphosphorylated tau proteins and neurofilaments $[15,77]$. The formation of NFTs is directly associated with neuronal dysfunction and the number of NFTs are related to the degree of dementia in $\mathrm{AD}$ [81]. It has been suggested that many years prior to the appearance of clinical signs of $\mathrm{AD}$ [5] the deposition of both NFT and A $\beta$ occurs within the neocortex, hippocampus, and other cognition-related subcortical structures [15]. Increasing evidence shows that $A \beta$ can be internalized or produced inside of the cells. This provides the opportunity for $A \beta$ to facilitate NFT formation [82]. On the other hand, the disruption in tau formation can influence the production of $A \beta$ and amyloid plaques $[82,83]$. Three major pathways have been proposed to illustrate the link between $A \beta$ and tau pathology. First, the activation of tau kinases by $A \beta$ induces NFT formation through tau hyperphosphorylation. Second, $A \beta$ decreases tau degradation by the promotion of proteasome dysfunction and, finally, A $\beta$ activates caspase-3, which causes the truncation of tau and altered tau aggregation that leads to NFT formation (fig. 2) [84]. Since immunotherapy with anti-A $\beta$ antibodies in a triple transgenic mouse model of $\mathrm{AD}$ reduced $\mathrm{A} \beta$ accumulation and slowed the formation of NFT, it seems that $A \beta$ is also involved in the formation of NFTs [85]. This surmise is supported by the fact that during AD development NFTs gradually accumulate in limbic areas and in the isocortex after $A \beta$ aggregation and cause dementia and cognitive dysfunction [80]. 
Fig. 2. Interrelationship between $A \beta$ and NFT formation.

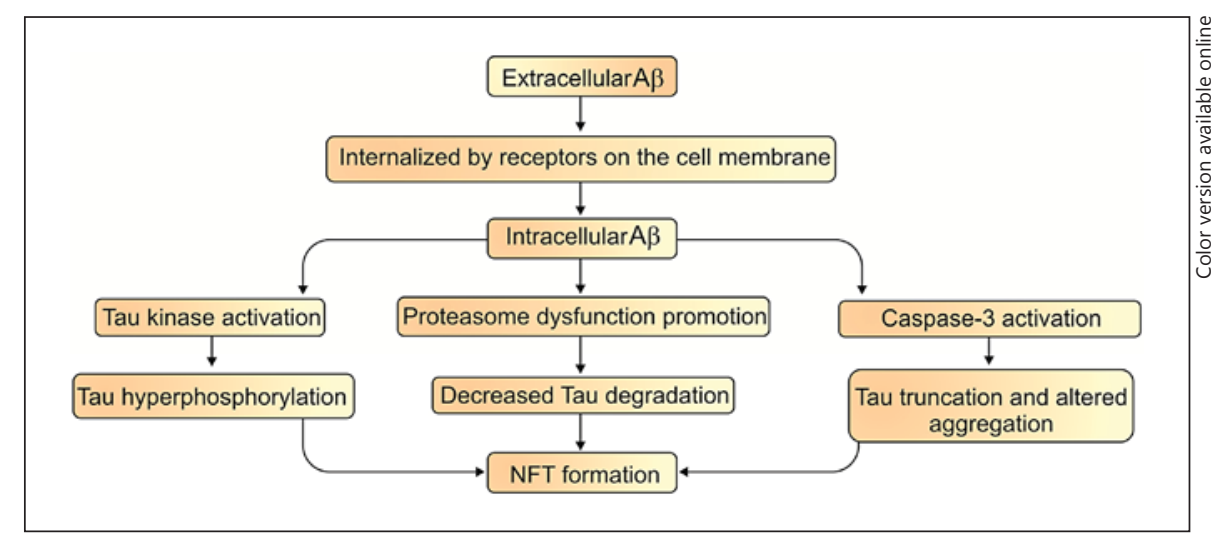

\section{Synthetic and Naturally Secreted A $\beta$}

$\mathrm{A} \beta$ assemblies are classified as synthetic and naturally secreted forms. Synthetic A $\beta$ oligomers include 10,40 or 42 peptides and mimic the most common forms of $A \beta$ which are found in both $\mathrm{AD}$ and the normal human brain [86]. It has recently been shown that synthetic $A \beta$ dimers which mimic the natural ones can make some stable protofibrils that persist for a long time and impair synaptic plasticity [87]. Moreover, these synthetic forms of $A \beta$ are chemically defined and can be readily synthesized and biophysically characterized [46]. On the other hand, for the achievement of adequate memory disruption in animals these forms of $A \beta$ must be used at higher doses [50].

Naturally secreted $A \beta$ peptides are usually obtained from $\mathrm{CHO}$ (cultured Chinese hamster ovary) cells which stably overexpress $\mathrm{APP}_{\mathrm{V} 717 \mathrm{~F}}$ (a mutant form of $\mathrm{APP}$ known to cause the familial form of $\mathrm{AD}$ ) $[50,88]$ and release soluble oligomers (dimmers, trimmers and tetramers) and monomers of $A \beta[50,86]$. Importantly, biochemical properties of $A \beta$ assemblies derived from this cell line have been reported [50]. There are some other natural forms of $A \beta$ which can be produced in the brains of patients with $A D$, including $A \beta_{25-35}$. $A \beta_{25-35}$ is a fragment of full-peptide $A \beta$ [89]. It forms $\beta$-sheets similarly, which provoke neuronal cell death, memory impairment and synaptic damage $[90,91]$. Recent evidence shows that a single-dose intracerebroventricular injection of this form can mimic some main neuropathological signs of $\mathrm{AD}$ in its early stages in rats [92].

As mentioned above, synthetic forms of $A \beta$ contain predefined lengths of peptides, whereas $\mathrm{CHO}$-derived $\mathrm{A} \beta$ assemblies, like other naturally produced brain and CSF $\mathrm{A} \beta$ peptides, are heterogeneous in length. On the other hand, unlike the synthetic forms of $A \beta$, naturally produced $A \beta$ peptides exert their biological effects only at very low doses and, therefore, they are able to effectively disrupt memory and long-term potentiation in animal models $[48,50]$.

\section{A $\beta$-Based Rodent Models}

$\mathrm{A} \beta$ is able to induce neurotoxicity directly and cause destruction in cholinergic basal forebrain projections [21]; moreover, it can disrupt memory skills in experimental models. Different doses of synthetic and/or naturally secreted $A \beta$ peptides are stereotactically delivered into the brain through intracerebroventricular $[46,48,93$, 94] and/or intrahippocampal injections for the induction of experimental AD in rodents [95].

Nowadays, transgenic and knockout rodents [96, 97] have been developed as well as other transgenic models such as Caenorhabditis elegans [98, 99], Drosophila melanogaster [100] and viral vector-driven models of AD [101], but mice are by far the most used genus. Due to the complexity of $\mathrm{AD}$, it has been difficult to create a transgenic model that replicates the multiple characteristics of the disease. Thus, most of the transgenic models that have been generated to date exhibit some of the major pathological hallmarks of AD [102]. By considering amyloid importance in $\mathrm{AD}$ pathogenesis, the main focus of modeling studies is on amyloid deposition [101]. After the discovery of familial AD mutations in APP, modeling studies focused on making AD models based on the overexpression of transgenes containing familial $\mathrm{AD}$ mutations [103]. The first predication of the AD transgenic model was reported in 1995 [104], which expressed high levels of mutant APP to generate extracellular A $\beta$ in specific parts of the brain [105]. Consequently, numerous models have been successfully developed which are deposits of amyloid plaque [106]. Some of these models are shown in table 1. 
Table 1. Some of amyloid-based transgenic animal models of AD

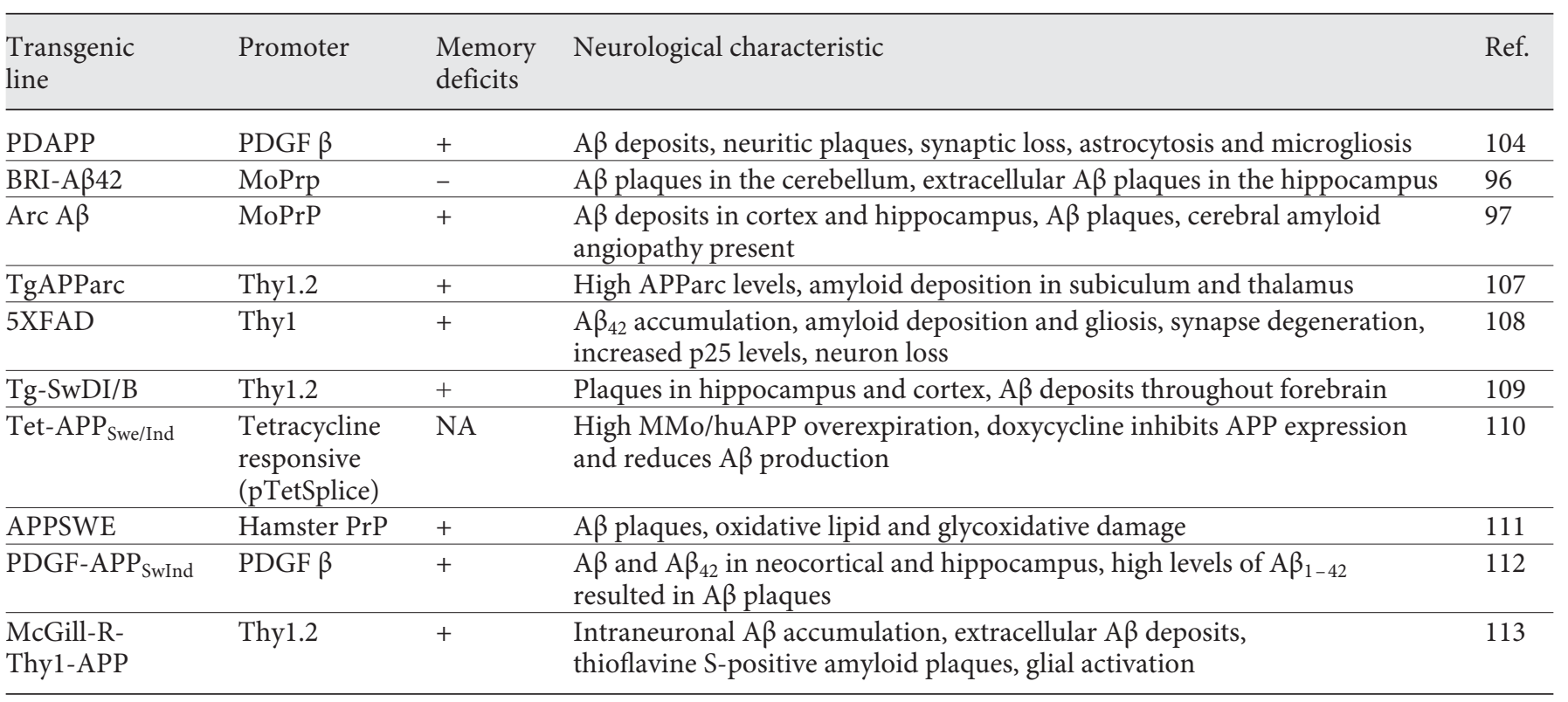

$\mathrm{NA}=$ Not assessed

The type of mutation affects plaque formation in models. For example, mutations at the $\mathrm{N}$ terminus of $A \beta$ lead to an increase in $A \beta_{40}$ and $A \beta_{42}$, whereas mutations at the $\mathrm{C}$ terminus lead to an increase in the $\mathrm{A} \beta_{1-42}$ form [102]. However, a mutant of the amyloid-related gene carrier has been crossed with the human APP overexpressing line in these models. Most of these models express transgenic APP at an extremely higher level than the endogenous APP. Most of the transgenic animals exhibit agedependent amyloid deposition similar to that found in AD.

\section{Conclusion}

The most common neurodegenerative disorder and the most important cause of dementia in elderly people appears to be $\mathrm{AD}$, and $\mathrm{A} \beta$ peptide has a substantial role in its pathogenesis. The appearance of $A \beta$ occurs many years before the clinical signs and symptoms of the disease, so it could be a reliable biomarker for $\mathrm{AD}$ prediction. As indicated, $A \beta$ plays an important role in the formation of both amyloid plaques and NFTs, which gradually leads to $\mathrm{AD}$. $\mathrm{A} \beta$ deposition leads to synaptic degeneration and interacts with different types of central nervous system receptors; hence, it disrupts neuronal homeostasis. Moreover, $A \beta$ deposition along the cerebral vessels alters their tonicity and triggers some of the cerebrovascular deficits. Furthermore, its accumulation disrupts intracellular $\mathrm{Ca}^{2+}$ homeostasis which ultimately reduces neuronal $\mathrm{Ca}^{2+}$ buffering capacity and increases excitotoxicity outcomes. Also, $A \beta$ peptides may fold in different ways and show a prion-like pathology in the brain of $\mathrm{AD}$ patients.

Recently, most of the efforts have been directed to controlling the production and clearance of $A \beta$. Interestingly, given this, anti-A $\beta$ monoclonal antibodies have been developed as a novel strategy in the treatment of AD. Furthermore, animal models related to $A \beta$ neurotoxicity have been developed for the better understanding of $\mathrm{AD}$ and for the testing of new strategies against it. The exact mechanisms of this peptide are unclear and more studies need to be done to clarify them.

\section{Acknowledgment}

The authors would like to express their gratitude to Dr. Mohammad R. Rashidi, Vice Chancellor, Research and Technology, Tabriz University of Medical Sciences, Tabriz, Iran for spiritual auspices.

\section{Disclosure Statement}

The authors have no conflicts of interest to disclose. 


\section{References}

1 Koudinov AR, Berezov TT: Alzheimer's amyloid-beta $(A \beta)$ is an essential synaptic protein, not neurotoxic junk. Acta Neurobiol Exp 2004;64:71-79.

-2 Carlo MD: Simple model systems: a challenge for Alzheimer's disease. Immun Ageing 2012; 9:3.

$>3$ Qiu C, Kivipelto M, von Strauss E: Epidemiology of Alzheimer's disease: occurrence, determinants, and strategies toward intervention. Dialogues Clin Neurosci 2009;11:111-128.

4 Anstey KJ, Cherbuin N, Herath PM, et al: A self-report risk index to predict occurrence of dementia in three independent cohorts of older adults: the ANU-ADRI. PLoS One 2014; 9:e86141.

$>5$ Nordberg A: Amyloid plaque imaging in vivo: current achievement and future prospects. Eur J Nucl Med Mol Imaging 2007;35:46-50.

$\checkmark 6$ Mehan S, Arora R, Sehgal V, et al: Inflammatory diseases - immunopathology, clinical and pharmacological bases; in Khatami $\mathrm{M}$ (ed): Dementia: A Complete Literature Review on Various Mechanisms Involved in Pathogenesis and an Intracerebroventricular Streptozotocin-Induced Alzheimer's Disease. Rijeka, InTech, 2012, pp 3-19.

$>7$ Khorrami A, Ghanbarzadeh S, Mahmoudi J, et al: Investigation of the memory impairment in rats fed with oxidized-cholesterol-rich diet employing passive avoidance test. Drug Res (Stuttg) 2014, DOI: 10.1055/s0034-1370950.

$>8$ Grienberger C, Rochefort NL, Adelsberger H, et al: Staged decline of neuronal function in vivo in an animal model of Alzheimer's disease. Nat Commun 2012;774:1-10.

$>9$ Gotz J, Ittner LM: Animal models of Alzheimer's disease and frontotemporal dementia. Nat Rev Neurosci 2008;9:532-544.

10 Sadigh-Eteghad S, Majdi A, Farhoudi M, et al: Different patterns of brain activation in normal aging and Alzheimer's disease from cognitional sight: meta-analysis using activation likelihood estimation. J Neurol Sci 2014;343:159-166.

$>11$ Graham MM: Clinical molecular imaging with radiotracers: current status. Med Princ Pract 2012;21:197-208.

12 Dubois B, Feldman HH, Jacova C, et al: Research criteria for the diagnosis of Alzheimer's disease: revising the NINCDS-ADRDA criteria. Lancet Neurol 2007;6:734-746.

13 Butterfield DA, Boyd-Kimball D: Amyloid $\beta$-peptide - $_{1-42}$ contributes to the oxidative stress and neurodegeneration found in $\mathrm{Alz}$ heimer disease brain. Brain Pathol 2004; 14: 426-432.

14 Ittner LM, Ke YD, Delerue F, et al: Dendritic function of tau mediates amyloid-beta toxicity in Alzheimer's disease mouse models. Cell 2010;142:387-397.

15 Moreira PI, Carvalho C, Zhu X, et al: Mitochondrial dysfunction is a trigger of Alzheimer's disease pathophysiology. Biochim Biophys Acta 2010;1802:2-10.
16 Findeis MA: The role of amyloid $\beta$-peptide 42 in Alzheimer's disease. Pharmacol Ther 2007; 116:266-286.

17 Bao F, Wicklund L, Lacor PN, et al: Different $\beta$-amyloid oligomer assemblies in Alzheimer brains correlate with age of disease onset and impaired cholinergic activity. Neurobiol Aging 2012;33:825.e1-e13.

18 Esparza TJ, Zhao H, Cirrito JR, et al: Amyloidbeta oligomerization in Alzheimer dementia versus high-pathology controls. Ann Neurol 2013;73:104-119.

19 O'Brien RJ, Wong PC: Amyloid precursor protein processing and Alzheimer's disease. Annu Rev Neurosci 2011;34:185-204.

20 Cole SL, Vassar R: The Alzheimer's disease beta-secretase enzyme, BACE1. Mol Neurodegener 2007;2:22.

21 Harkany T, Abraham I, Timmerman W, et al: $\beta$-Amyloid neurotoxicity is mediated by a glutamate-triggered excitotoxic cascade in rat nucleus basalis. Eur J Neurosci 2000;12:27352745 .

22 Selkoe DJ: The cell biology of beta-amyloid precursor protein and presenilin in Alzheimer's disease. Trends Cell Biol 1998;8:447-453.

23 Cheng Y, Judd TC, Bartberger MD, et al: From fragment screening to in vivo efficacy: optimization of a series of 2-aminoquinolines as potent inhibitors of beta-site amyloid precursor protein-cleaving enzyme 1 (BACE1). J Med Chem 2011;54:5836-5857.

24 Ridge PG, Ebbert MT, Kauwe JS: Genetics of Alzheimer's disease. Biomed Res Int 2013;25: 49-54.

25 Casserly I, Topol E: Convergence of atherosclerosis and Alzheimer's disease: inflammation, cholesterol, and misfolded proteins. Lancet 2004;363:1139-1146.

26 Kirkitadze MD, Kowalska A: Molecular mechanisms initiating amyloid- $\beta$ fibril formation in Alzheimer's disease. Acta Biochim Pol 2005;52:417-423.

$>27$ Sadigh-Eteghad S, Talebi M, Farhoudi M: Association of apolipoprotein E epsilon 4 allele with sporadic late onset Alzheimer's disease; a meta-analysis. Neurosciences 2012;17:321326.

28 Nunomura A, Castellani RJ, Lee $\mathrm{Hg}$, et al: Neuropathology in Alzheimer's disease: awaking from a hundred-year-old dream. Sci Aging Knowledge Environ 2006;8:pe10.

29 Shankar GM, Walsh DM: Alzheimer's disease: synaptic dysfunction and $\mathrm{A} \beta$. Mol Neurodegener 2009;4:48-61.

30 Kanekiyo T, Cirrito JR, Liu CC, et al: Neuronal clearance of amyloid-beta by endocytic receptor LRP1. J Neurosci 2013;33:1927619283.

31 Lam FC, Liu R, Lu P, et al: $\beta$-Amyloid efflux mediated by P-glycoprotein. J Neurochem 2001;76:1121-1128.
32 Cirrito JR, Deane R, Fagan AM, et al: P-glycoprotein deficiency at the blood-brain barrier increases amyloid-beta deposition in an Alzheimer disease mouse model. J Clin Invest 2005;115:3285-3290.

33 Wang YJ, Zhou HD, Zhou XF: Clearance of amyloid-beta in Alzheimer's disease: progress, problems and perspectives. Drug Discov Today 2006;11:931-938.

34 Caccamo A, Oddo S, Sugarman MC, et al: Age- and region-dependent alterations in $\mathrm{A} \beta$ degrading enzymes: implications for $A \beta$ induced disorders. Neurobiol Aging 2005;26: 645-654.

35 Qiu WQ, Folstein MF: Insulin, insulin-degrading enzyme and amyloid-beta peptide in Alzheimer's disease: review and hypothesis. Neurobiol Aging 2006;27:190-198.

36 Palmer JC, Baig S, Kehoe PG, et al: Endothelin-converting enzyme- 2 is increased in $\mathrm{Alz}$ heimer's disease and up-regulated by A $\beta$. Am J Pathol 2009; 175:262-270.

37 Wildsmith KR, Holley M, Savage JC, et al: Evidence for impaired amyloid-beta clearance in Alzheimer's disease. Alzheimers Res Ther 2013;5:33.

38 Mawuenyega KG, Sigurdson W, Ovod V, et al: Decreased clearance of CNS beta-amyloid in Alzheimer's disease. Science 2010;330: 1774 .

39 Sadigh-Eteghad S, Talebi M, Farhoudi M, et al: $\beta$-Amyloid exhibits antagonistic effects on alpha 7 nicotinic acetylcholine receptors in orchestrated manner. J Med Hypotheses Ideas 2014;8:49-52.

40 Kontusha A, Berndta C, Webera W, et al: Amyloid- $\beta$ is an antioxidant for lipoproteins in cerebrospinal fluid and plasma. Free Radic Biol Med 2001;30:119-128.

41 Attems J, Yamaguchi H, Saido TC, et al: Capillary CAA and perivascular $\mathrm{A} \beta$-deposition: two distinct features of Alzheimer's disease pathology. J Neurol Sci 2010;299:155-162.

42 Kihara T, Shimohama S: Alzheimer's disease and acetylcholine receptors. Acta Neurobiol Exp 2004;64:99-105.

43 Hardy J, Selkoe DJ: The amyloid hypothesis of Alzheimer's disease: progress and problems on the road to therapeutics. Science 2002;297: 353-356.

44 Barry AE, Klyubin I, Donald JMM, et al: Alzheimer's disease brain-derived amyloid- $\beta$ mediated inhibition of LTP in vivo is prevented by immunotargeting cellular prion protein. J Neurosci 2011;31:7259 -7263.

45 Shankar GM, Li S, Mehta TH, et al: Amyloid- $\beta$ protein dimers isolated directly from Alzheimer's brains impair synaptic plasticity and memory. Nat Med 2008;14:837-842.

46 Balducci C, Beeg M, Stravalaci M, et al: Synthetic amyloid- $\beta$ oligomers impair long-term memory independently of cellular prion protein. Proc Natl Acad Sci USA2010;107:22952300. 
47 Shen C-L, Fitzgerald MC, Murphy RM: Effect of acid predissolution on fibril size and fibril flexibility of synthetic $\beta$-amyloid peptide. Biophys J 1994;67:1238-1246.

-48 Kittelberger KA, Piazza F, Tesco G, et al: Natural amyloid-beta oligomers acutely impair the formation of a contextual fear memory in mice. PLoS One 2012;7:e29940.

-49 Jin M, Shepardson N, Yang T, et al: Soluble amyloid-beta protein dimers isolated from Alzheimer cortex directly induce tau hyperphosphorylation and neuritic degeneration. Proc Natl Acad Sci USA 2011;108:5819-5824.

-50 Townsend M, Shankar GM, Mehta T, et al: Effects of secreted oligomers of amyloid $\beta$-protein on hippocampal synaptic plasticity: a potent role for trimers. J Physiol 2006;572: 477-492.

51 Popugaeva E, Bezprozvanny I: Role of endoplasmic reticulum $\mathrm{Ca}^{2+}$ signaling in the pathogenesis of Alzheimer disease. Front Mol Neurosci 2013;6:29.

-52 Supnet C, Grant J, Kong H, et al: Amyloid- $\beta_{1-42}$ increases ryanodine receptor- 3 expression and function in neurons of TgCRND8 mice. J Biol Chem 2006;281:38440-38447.

53 Danysz W, Parsons CG: Alzheimer's disease, beta-amyloid, glutamate, NMDA receptors and memantine - searching for the connections. Br J Pharmacol 2012;167:324-352.

54 Nakajima C, Kulik A, Frotscher M, et al: LDL receptor-related protein 1 (LRP1) modulates $\mathrm{N}$-methyl-D-aspartate (NMDA) receptor-dependent intracellular signaling and NMDAinduced regulation of postsynaptic protein complexes. J Biol Chem 2013;30:2190921923.

-55 Kang DE, Pietrzik CU, Baum L, et al: Modulation of amyloid $\beta$-protein clearance and Alzheimer's disease susceptibility by the LDL receptor-related protein pathway. J Clin Invest 2000;106:1159-1166.

56 Kanekiyo T, Bu G: The low-density lipoprotein receptor-related protein 1 and amyloidbeta clearance in Alzheimer's disease. Front Aging Neurosci 2014;6:93.

57 Andersen OM, Reiche J, Schmidt V, et al: Neuronal sorting protein-related receptor sorLA/LR11 regulates processing of the amyloid precursor protein. Proc Natl Acad Sci USA 2005;102:13461-13466.

58 Rogaeva E, Meng Y, Lee JH, et al: The neuronal sortilin-related receptor SORL1 is genetically associated with Alzheimer disease. Nat Genet 2007;39:168-177.

59 Park L, Zhou J, Zhou P, et al: Innate immunity receptor CD36 promotes cerebral amyloid angiopathy. Proc Natl Acad Sci USA 2013;110:3089-3094.

60 Le Y, Gong W, Tiffany HL, et al: Amyloid- $\beta_{42}$ activates a G-protein-coupled chemoattractant receptor, FPR-like-1. J Neurosci 2001; 21:RC123.

61 Perez SE, He B, Muhammad N, et al: Cholinotrophic basal forebrain system alterations in 3xTg-AD transgenic mice. Neurobiol Dis 2011;41:338-352.
62 Bulbarelli A, Lonati E, Cazzaniga E, et al: TRKA pathway activation induced by amyloid-beta (A $\beta$ ). Mol Cell Neurosci 2009;40: 365-373.

63 Fulop T, Lacombe G, Cunnane S, et al: Elusive Alzheimer's disease: can immune signatures help our understanding of this challenging disease? Part 2. New immune paradigm. Discov Med 2013;15:33-42.

64 Weksler ME, Gouras G, Relkin NR, et al: The immune system, amyloid-beta peptide, and Alzheimer's disease. Immunol Rev 2005;205: 244-256.

65 Bohrmann B, Baumann K, Benz J, et al: Gantenerumab: a novel human anti- $\mathrm{A} \beta$ antibody demonstrates sustained cerebral amyloid- $\beta$ binding and elicits cell-mediated removal of human amyloid- $\beta$. J Alzheimers Dis 2012;28: 49-69.

66 Panza F, Frisardi V, Solfrizzi V, et al: Immunotherapy for Alzheimer's disease: from anti$\beta$-amyloid to tau-based immunization strategies. Immunotherapy 2012;4:213-238.

67 Ridolfi E, Barone C, Scarpini E, et al: The role of the innate immune system in Alzheimer's disease and frontotemporal lobar degeneration: an eye on microglia. Clin Dev Immunol 2013;2013:939786.

68 Boutajangout A, Wisniewski T: The innate immune system in Alzheimer's disease. Int Cell Biol 2013;2013:576383.

69 Forloni G, Sclip A, Borsello T, et al: The neurodegeneration in Alzheimer disease and the prion protein. Prion 2013;7:60-65.

70 Peggion C, Sorgato MC, Bertoli A: Prions and prion-like pathogens in neurodegenerative disorders. Pathogens 2014;3:149-163.

71 Um JW, Nygaard HB, Heiss JK, et al: Alzheimer amyloid- $\beta$ oligomer bound to postsynaptic prion protein activates Fyn to impair neurons. Nat Neurosci 2012;15:1227-1235.

72 Rushworth JV, Griffiths HH, Watt NT, et al: Prion protein-mediated toxicity of amyloidbeta oligomers requires lipid rafts and the transmembrane LRP1. J Biol Chem 2013;288: 8935-8951.

73 Brundin P, Melki R, Kopito R: Prion-like transmission of protein aggregates in neurodegenerative diseases. Proc Natl Acad Sci USA 2010;11:301-307.

74 Mohorko N, Bresjanac M: Tau protein and human tauopathies: an overview. Zdrav Vestn 2008;77:35-41.

75 Buee L, Bussiere T, Buee-Scherrer V, et al: Tau protein isoforms, phosphorylation and role in neurodegenerative disorders. Brain Res Rev 2000;33:95-130.

76 Kimura T, Whitcomb DJ, Jo J, et al: Microtubule-associated protein tau is essential for long-term depression in the hippocampus. Philos Trans R Soc Lond B Biol Sci 2014;369: 20130144

77 Goedert M, Spillantini MG: A century of Alzheimer's disease. Science 2006;314:777-781.
78 Davidowitz EJ, Chatterjee I, Moe JG: Targeting tau oligomers for therapeutic development for Alzheimer's disease and tauopathies. Curr Topics Biotechnol 2008;4:47-64.

79 Gotz J, Probst A, Spillantini MG, et al: Somatodendritic localization and hyperphosphorylation of tau protein in transgenic mice expressing the longest human brain tau isoform. EMBO J 1995;7:1304-1313.

80 Kimura T, Yamashita S, Fukuda T, et al: Hyperphosphorylated tau in parahippocampal cortex impairs place learning in aged mice expressing wild-type human tau. EMBO J 2007; 26:5143-5152.

81 Brion J-P: Neurofibrillary tangles and Alzheimer's disease. Eur Neurol 1998;40:130-140.

82 Blurton-Jones M, Laferla FM: Pathways by which $A \beta$ facilitates tau pathology. Curr Alzheimer Res 2006;3:437-448.

83 Mazzitelli S, Xu P, Ferrer I, et al: The loss of c-JUN N-terminal protein kinase activity prevents the amyloidogenic cleavage of amyloid precursor protein and the formation of amyloid plaques in vivo. J Neurosci 2011;31: 16969-16976.

84 Luan K, Rosales JL, Lee K-Y: Viewpoint: crosstalks between neurofibrillary tangles and amyloid plaque formation. Ageing Res Rev 2013;12:174-181.

85 Oddo S, Billings L, Kesslak JP, et al: A $\beta$ immunotherapy leads to clearance of early, but not late, hyperphosphorylated tau aggregates via the proteasome. Neuron 2004;43:321-332.

86 Selkoe DJ: Soluble oligomers of the amyloid $\beta$-protein impair synaptic plasticity and behavior. Behav Brain Res 2008;192:106-113.

87 O’Nuallain B, Klyubin I, Mc Donald JM, et al: A monoclonal antibody against synthetic $A \beta$ dimer assemblies neutralizes brain-derived synaptic plasticity-disrupting $A \beta$. J Neurochem 2011;119:189-201.

88 Shankar GM, Bloodgood BL, Townsend M, et al: Natural oligomers of the Alzheimer amyloid- $\beta$ protein induce reversible synapse loss by modulating an NMDA type glutamate receptor-dependent signaling pathway. J Neurosci 2007;27:2866 -2875.

89 Kubo T, Nishimura S, Kumagae Y, et al: In vivo conversion of racemized $\beta$-amyloid ([D$\left.\left.\mathrm{Ser}^{26}\right] \mathrm{A} \beta_{1-40}\right)$ to truncated and toxic fragments ([D-Ser $\left.{ }^{26}\right] \quad A \beta_{25-35 / 40}$ ) and fragment presence in the brains of Alzheimer's patients. J Neurosci Res 2002;70:474-483.

90 Pike CJ, Walencewicz-Wasserman AJ, Kosmoski J, et al: Structure-activity analyses of $\beta$-amyloid peptides: contributions of the $\beta 25-$ 35 region to aggregation and neurotoxicity. J Neurochem 1995;64:253-265.

91 Palop JJ, Mucke L: Amyloid- $\beta$-induced neuronal dysfunction in Alzheimer's disease: from synapses toward neural networks. Nat Neurosci 2010;13:812-818.

92 Awale S, Tohda C, Tezuka Y, et al: Protective effects of Rosa damascena and its active constituent on $\mathrm{A} \beta_{25-35}$-induced neuritic atrophy. Evid Based Complement Alternat Med 2011; 2011:1-9. 
\$93 Walsh DM, Klyubin I, Fadeeva JV, et al: Naturally secreted oligomers of amyloid $\beta$-protein potently inhibit hippocampal long-term potentiation in vivo. Nature 2002; 416:535-539.

-94 Kim J-H, Anwyl R, Suh Y-H, et al: Use-dependent effects of amyloidogenic fragments of $\beta$-amyloid precursor protein on synaptic plasticity in rat hippocampus in vivo. J Neurosci 2001;21:1327-1333.

-95 Cetin F, Dincer S: The effect of intrahippocampal beta-amyloid ${ }_{1-42}$ peptide injection on oxidant and antioxidant status in rat brain. Ann NY Acad Sci 2007;1100:510-517.

96 McGowan E, Pickford F, Kim J, et al: $A \beta_{42}$ is essential for parenchymal and vascular amyloid deposition in mice. Neuron 2005;42: 191-199.

-97 Knobloch M, Konietzko U, Krebs DC, et al: Intracellular $A \beta$ and cognitive deficits precede $\beta$-amyloid deposition in transgenic $\operatorname{arcA} \beta$ mice. Neurobiol Aging 2007;28: 1297-1306.

$\$ 98$ Link CD: Expression of human $\beta$-amyloid peptide in transgenic Caenorhabditis elegans. Proc Natl Acad Sci USA 1995;92:93689372.

$\checkmark 99$ Wu Y, Luo Y: Transgenic C. elegans as a model in Alzheimer's research. Curr Alzheimer Res 2005;2:37-45.

100 Gunawardena S, Goldstein LS: Disruption of axonal transport and neuronal viability by amyloid precursor protein mutations in drosophila. Neuron 2001;32:389-401.
101 Rockenstein E, Crews L, Masliah E: Transgenic animal models of neurodegenerative diseases and their application to treatment development. Adv Drug Deliv Rev 2007;59: 1093-1102.

102 Duff K, Suleman F: Transgenic mouse models of Alzheimer's disease: how useful have they been for therapeutic development? Brief Funct Genomic Proteomic 2004;3:4759.

103 Elder GA, Sosa MAG, Gasperi RD: Transgenic mouse models of Alzheimer's disease. Mt Sinai J Med 2010;77:69-81.

104 Games D, Adams D, Alessandrini R, et al: Alzheimer-type neuropathology in transgenic mice overexpressing V717F $\beta$-amyloid precursor protein. Nature 1995;373:523527.

105 Duff K: Transgenic mouse models of Alzheimer disease; in Davis KL, Charney D, Coyle JT, Nemeroff C (eds): Neuropsychopharmacology: The Fifth Generation of Progress. Brentwood, American College of Neuropsychopharmacology, 2002, p 1215.

106 Oddo S, Caccamo A, Shepherd JD, et al: Triple-transgenic model of Alzheimer's disease with plaques and tangles: intracellular $\mathrm{A} \beta$ and synaptic dysfunction. Neuron 2003;39: 409-421.

107 Ronnback A, Zhu S, Dillner K, et al: Progressive neuropathology and cognitive decline in a single arctic APP transgenic mouse model. Neurobiol Aging 2011;32:280-292.
08 Oakley H, Cole SL, Logan S, et al: Intraneuronal $\beta$-amyloid aggregates, neurodegeneration, and neuron loss in transgenic mice with five familial Alzheimer's disease mutations: potential factors in amyloid plaque formation. J Neurosci 2006;26:10129_ 10140.

109 Davis J, Xu F, Deane R, et al: Early-onset and robust cerebral microvascular accumulation of amyloid $\beta$-protein in transgenic mice expressing low levels of a vasculotropic Dutch/ Iowa mutant form of amyloid $\beta$ protein precursor. J Biol Chem 2004;279:20296-20306.

110 Jankowsky JL, Slunt HH, Gonzales V, et al Persistent amyloidosis following suppression of $\mathrm{A} \beta$ production in a transgenic model of Alzheimer disease. PLoS Med 2005;2: 1318-1333.

111 Hsiao K, Chapman P, Nilsen S, et al: Correlative memory deficits, $\mathrm{A} \beta$ elevation, and amyloid plaques in transgenic mice. Science 1996;274:99-102.

112 Mucke L, Masliah E, Yu G-Q, et al: Highlevel neuronal expression of $\mathrm{A} \beta_{1-42}$ in wildtype human amyloid protein precursor transgenic mice: synaptotoxicity without plaque formation. J Neurosci 2000;20:40504058.

113 Leon WC, Canneva F, Partridge V, et al: A novel transgenic rat model with a full $\mathrm{Alz}$ heimer's-like amyloid pathology displays pre-plaque intracellular amyloid- $\beta$ associated cognitive impairment. J Alzheimers Dis 2010;20:113-126. 